\title{
Effects of Different Forms and Doses of Sulphur Application on Wheat
}

\author{
Halil Erdem $^{1 *}$, Mustafa Bulent Torun ${ }^{2}$, Nazife Erdem ${ }^{1}$, Atilla Yazıcı ${ }^{3}$, Inci Tolay ${ }^{4}$, Elif Gunal $^{1}$, \\ Faruk Özkutlus
}

${ }^{1}$ Soil Science and Plant Nutrition Department, Faculty of Agriculture, Gaziosmanpasa University, 60240 Tokat, Turkey;

${ }^{2}$ Soil Science and Plant Nutrition Department, Faculty of Agriculture, Cukurova University, 01330 Adana, Turkey.

${ }^{3}$ Faculty of Engineering and Natural Sciences, Sabanci University, 34956 Istanbul, Turkey

${ }^{4}$ Soil Science and Plant Nutrition Department, Faculty of Agriculture, Akdeniz University, 07058 Antalya, Turkey.

${ }^{5}$ Soil Science and Plant Nutrition Department, Faculty of Agriculture, Ordu University, 52200 Ordu, Turkey

\section{A R T I C L E I N F O}

Article history:

Received 13 June 2016

Accepted 16 July 2016

Available online, ISSN: 2148-127X

Keywords:

Sulphur fertilizer

Sulphur forms

Wheat

Dry matter

Spad value

${ }^{*}$ Corresponding Author:

E-mail: halil.erdem@gop.edu.tr

\section{A B S T R A C T}

Deficiency of sulphur (S) is an important limiting factor of plant growth for sustainable agricultural production. The decline in sulphur dioxide emission, decrease in S-containing fertilizer consumption due to the high cost of S-fertilizers, breeding of new high yielding species are the well known causes of S-deficiency. A greenhouse experiment was conducted to investigate the effects of several doses of $\mathrm{K}_{2} \mathrm{SO}_{4}-\mathrm{S}, \mathrm{CaSO}_{4}-\mathrm{S}$ and elemental$\mathrm{S}$ applied on growth, shoot dry matter yield, $\mathrm{S}$ and $\mathrm{N}$ concentrations of wheat cultivar. The experiments were conducted in three soils differed from available $\mathrm{S}$ concentrations. Effects of different S-treatments $(0,25,50$ and $100 \mathrm{mg} \mathrm{S} \mathrm{kg-1)}$ and $\mathrm{S}$-forms had significant effects on shoot dry matter yields of plants. Sulphur from different S-sources did not increase shoot S-concentrations in Eskisehir and Konya soils, but increase was significant obtained in the Harran soil. Shoot S-concentration in Harran soil for zero $\mathrm{K}_{2} \mathrm{SO}_{4}$ treatment was $0.09 \%$, the values were $0.22,0.26$ and $0.27 \%$ respectively for 25 , 50 and $100 \mathrm{mg} \mathrm{kg}^{-1}$ treatments. The results indicated significant effects of S-treatments on plant growth and yield mostly based on soil properties, especially the available S-levels.

\section{Introduction}

The sulphur ( $\mathrm{S})$ is needed for the several functions of living organisms. The $\mathrm{S}$ is important in production of cysteine, thioredoxins, co-enzyme A, methionine, thiamine pyrophosphate, biotin, sulpholipids and methionine and cysteine containing proteins (Zhao et al., 1999; Scherer, 2001; Zehra and Khan, 2014; Capaldi et al., 2015). The lack of adequate $S$ lowers the crop yield and quality, due to the $S$ requirement for the synthesis of proteins and enzymes. (Zhao et al., 1999c). The importance of $\mathrm{S}$ in plant growth and quality has been accredited for a long time however, the S-deficiency in wheat has rarely been reported (Withers et al., 1995; Schonhof et al., 2007; Mascagni et al., 2008; Jonard et al., 2015). The decrease in the consumption of fertilizers with low $\mathrm{S}$ content, reduction in the emission of atmospheric sulphur dioxide, decline in the use of pesticides containing $\mathrm{S}$ and new high yielding cultivars creates the S-deficiency in agricultural soils (Eriksen et al., 2004).

The $\mathrm{S}$ transfer into soil from atmospheric sources was reported less than $10 \mathrm{~kg} / \mathrm{ha}$ in several European countries (Hu et al., 2005) which is much lower than the Srequirements of several plants (McGrath et al., 2002). Therefore, Sulphur Institute reported eleven million tons of S-deficiency in agricultural soils for the year 2010. The application of S-containing fertilizers to ameliorate the $\mathrm{S}$ deficiency improves plant growth and increases crop yield
(Habtegebrial and Singh, 2009; Staugaitis et al., 2014). Yield losses due to S-deficiency in field (Inal et al., 2003) and greenhouse (Erdem, 2004) experiments were also reported in Turkey. Although some reports are available investigating the effects of single $S$ sources on crop growth and yield, studies on different S-sources are limited. Thus, a greenhouse experiment was conducted to investigate the effects of various doses of $\mathrm{K}_{2} \mathrm{SO}_{4}-\mathrm{S}$, $\mathrm{CaSO}_{4}-\mathrm{S}$ and elemental-S applied on growth, shoot dry matter yield, $\mathrm{S}$ and $\mathrm{N}$ concentrations of two different wheat cultivars.

\section{Materials and Methods}

A greenhouse experiment was conducted with a bread wheat (Bezostaja), three different soils $((0.025 \mathrm{M} \mathrm{KCl}$ extractable S: Harran:14.7 mg $\mathrm{SO}_{4}-\mathrm{S} \mathrm{kg}^{-1}$, Eskişehir :12.2 $\mathrm{mg} \mathrm{SO}_{4}-\mathrm{S} \mathrm{kg}^{-1}$ and Konya: $18.3 \mathrm{mg} \mathrm{SO}_{4}-\mathrm{S} \mathrm{kg}^{-1}$; (Bloem et al.,2002)); three different sulphur sources $\left(\mathrm{K}_{2} \mathrm{SO}_{4}\right.$, $\mathrm{CaSO}_{4} \cdot 2 \mathrm{H}_{2} \mathrm{O}$ and Elemental-S) and four different sulphur doses $\left(0,25,50\right.$ and $\left.100 \mathrm{mg} \mathrm{S} \mathrm{kg}^{-1}\right)$. Some physical and chemical properties of the soils used in the experiment are given in table 1 . A total of $1.65 \mathrm{~kg}$ soil was placed and 12 seeds were planted into each pot. As base fertilizer, 350 $\mathrm{mg} \mathrm{N} \mathrm{kg}{ }^{-1}$ in $\mathrm{CaNO}_{3} .4 \mathrm{H}_{2} \mathrm{O}$ form, $100 \mathrm{mg} \mathrm{P} \mathrm{kg}^{-1}$ in $\mathrm{KH}_{2} \mathrm{PO}_{4}$ form, $2.5 \mathrm{mg} \mathrm{Fe} \mathrm{kg}{ }^{-1}$ in Fe-EDTA form and $2 \mathrm{mg}$ 
$\mathrm{Zn} \mathrm{kg}$ in $\mathrm{ZnCl}_{2}$ form were applied to each pot. Following the germination of seeds (when the plants were at 5 to $6 \mathrm{~cm}$ above the soil), number of plants was reduced to 9 . Pots were sustained almost at field capacity and irrigations were performed using distilled water. Plant growth was observed and S-deficiency symptoms of plants were recorded in a spad value with a chlorophyll meter (Minolta Spad 502). SPAD value is related to chlorophyll concentration of plants (Schaper and Chacko, 1991) and increased with increasing chlorophyll content. SPAD measurement was performed over the leaf just below the youngest full-grown leaf. Then, harvest time was determined based on symptom intensity. In this case, plants were harvested at $45^{\text {th }}$ day. Harvested plants were washed, dried at $70^{\circ} \mathrm{C}$ for 48 hours and dry weights were determined. Dry samples were milled and became ready for analysis. Shoot samples were etched within $\mathrm{H}_{2} \mathrm{O}_{2}$ $\mathrm{HNO}_{3}$ acid mixture in a microwave (Milestone 1200 Mega) for S-analysis. S-content of resultant extract was measured by using Inductively Coupled Plasma-Atomic Emission Spectrometry (ICP-AES) device at $182.562 \mathrm{~nm}$ wavelength.

JUMP software was used for statistical analysis of data in accordance with factorial experimental design with randomized split plots (Kalayc1, 2005).

\section{Results}

Effects of sulphur treatments on plant symptom level and shoot dry matter yield: Effects of different $\mathrm{S}$ treatments $\left(0,25,50\right.$ and $\left.100 \mathrm{mg} \mathrm{S} \mathrm{kg}^{-1}\right)$ on symptom level, growth and shoot dry matter yield varied related to the soil types used in experiments. While the spad value of Eskisehir soil for $\mathrm{K}_{2} \mathrm{SO}_{4}$ treatment was 39 in control treatment with zero $\mathrm{S}$ - application, spad values were respectively found to be 41,42 , and 45 in increasing treatment doses. Similar results were obtained for $\mathrm{CaSO}_{4}$ but the results for elemental-S were differed (Table 2). Similar findings were also determined for Konya soil (Table 1). However, S-treatments relieved S-symptoms of plants in Harran soil. While the spad value of control treatment was 26 , the values reached to 37,38 and 37 respectively for 25,50 and $100 \mathrm{mg} \mathrm{kg}^{-1} \mathrm{~K}_{2} \mathrm{SO}_{4}$ treatments (Table 2). These findings indicated difference in the effects of S-treatments on plant growth for different soils. Results also indicated significant effects of S-sources on spad value and effects in Harran soil were significantly distinctive.

S-treatments had significant effects on shoot dry matter yields of plants. Since the most distinctive symptom relieve was observed in Harran soil, the highest dry matter yield increase was also obtained in plant grown in Harran soil. While the average dry matter yield in zero $\mathrm{CaSO}_{4}$ treatments was $0.95 \mathrm{~g}$ plant $^{-1}$, the values were determined as $1.40,1.48$ and $1.52 \mathrm{~g} \mathrm{plant}^{-1}$, respectively for 25,50 and $100 \mathrm{mg} \mathrm{kg}^{-1} \mathrm{CaSO}_{4}$ treatments (Table 3). $\mathrm{CaSO}_{4}$ treatments caused increases in $47 \%, 56 \%$ and $60 \%$ yield, respectively in the same soil. Similar increases were also observed with $\mathrm{K}_{2} \mathrm{SO}_{4}$ and elemental-S treatments for the same soil. Results indicated significant effects of $\mathrm{S}$ - sources on dry matter yield (Table 3). Unlike Harran soil, effects of S-treatments on dry matter yield of cultivars grown in Eskisehir and Konya soils were not statistically distinctive. For instance, while dry matter yield of Eskisehir soil in zero elemental-S treatment was $1.54 \mathrm{~g}$ plant $^{-1}$, the value was $1.50 \mathrm{~g} \mathrm{plant}^{-1}$ in $100 \mathrm{mg} \mathrm{kg}^{-1}$ treatment (Table 3). The yields in Konya soil for the same treatments were respectively determined as 1.03 and 0.91 g plant ${ }^{-1}$ (Table 3). Yield increase with S-treatments of cultivars were not significant (Table 3).

Table 1 Some physical and chemical properties of the soils used in the experiment

\begin{tabular}{l|ccccc}
\hline Soil & $\mathrm{AS}$ & $\mathrm{pH}$ & $\mathrm{OM}$ & $\mathrm{CC}$ & Texture \\
\hline Konya & 18.3 & 7.93 & 2.5 & 26.2 & $\mathrm{C}$ \\
Eskişehir & 12.2 & 8.02 & 1.1 & 11.2 & $\mathrm{CL}$ \\
Harran & 14.7 & 7.71 & 1.2 & 27.8 & $\mathrm{C}$ \\
\hline
\end{tabular}

AS: Available-S (mg kg ${ }^{-1}$ ); OM: Organic M. (\%); CC: $\mathrm{CaCO} 3(\%)$

Table 2 Effects of different S-doses and different Ssources on SPAD values of plants grown in different soils.

\begin{tabular}{l|cccc}
\hline \multirow{2}{*}{ S Form } & $\begin{array}{c}\text { S Doses } \\
\left(\mathrm{mg} \mathrm{kg}^{-1}\right)\end{array}$ & Eskişehir & Konya & Harran \\
\cline { 3 - 5 } & 0 & 39 & 46 & 26 \\
$\mathrm{~K}_{2} \mathrm{SO}_{4}$ & 25 & 41 & 45 & 37 \\
& 50 & 42 & 47 & 38 \\
& 100 & 45 & 47 & 37 \\
\hline \multirow{5}{*}{$\mathrm{CaSO}_{4}$} & 0 & 37 & 45 & 24 \\
& 25 & 40 & 47 & 34 \\
& 50 & 43 & 45 & 38 \\
& 100 & 37 & 45 & 38 \\
\hline \multirow{5}{*}{$\mathrm{S}$} & 0 & 43 & 46 & 26 \\
& 25 & 43 & 47 & 31 \\
& 50 & 43 & 48 & 37 \\
& 100 & 44 & 47 & 41 \\
\hline
\end{tabular}

LSD $_{0,05}$ (Soil, S-Form, S-Dose): 0.432; 0.337; 0.523

Table 3 Effects of different S-doses and different Ssources on shoot dry matter yield $\left(\mathrm{g}\right.$ plant $\left.{ }^{-1}\right)$ of plants grown in different soils.

\begin{tabular}{|c|c|c|c|c|}
\hline \multirow{2}{*}{ S Form } & \multirow{2}{*}{$\begin{array}{l}\text { S Doses } \\
\left(\mathrm{mg} \mathrm{kg}^{-1}\right)\end{array}$} & Eskişehir & Konya & Harran \\
\hline & & \multicolumn{3}{|c|}{ Shoot Dry Weight $\left(\right.$ g plant $\left.^{-1}\right)$} \\
\hline \multirow{4}{*}{$\mathrm{K}_{2} \mathrm{SO}_{4}$} & 0 & 1.62 & 0.95 & 0.98 \\
\hline & 25 & 1.56 & 0.95 & 1.4 \\
\hline & 50 & 1.58 & 0.94 & 1.52 \\
\hline & 100 & 1.54 & 0.89 & 1.4 \\
\hline \multirow{4}{*}{$\mathrm{CaSO}_{4}$} & 0 & 1.43 & 0.97 & 0.95 \\
\hline & 25 & 1.44 & 0.94 & 1.4 \\
\hline & 50 & 1.52 & 0.91 & 1.48 \\
\hline & 100 & 1.3 & 0.86 & 1.52 \\
\hline \multirow{4}{*}{$\mathrm{S}$} & 0 & 1.54 & 1.03 & 0.94 \\
\hline & 25 & 1.42 & 0.92 & 1.23 \\
\hline & 50 & 1.58 & 0.88 & 1.36 \\
\hline & 100 & 1.5 & 0.91 & 1.44 \\
\hline
\end{tabular}


Effects of sulphur treatments on shoot $S$ and $N$ concentrations and N/S ratios of plants: Although sulphur from different $\mathrm{S}$-sources did not increase shoot $\mathrm{S}$ concentrations in Eskisehir and Konya soils, an increase was observed in Harran soil. While shoot S-concentration in Eskisehir soil for zero $\mathrm{K}_{2} \mathrm{SO}_{4}$ treatment was $0.22 \%$, the values were $0.21,0.22$ and $0.22 \%$ respectively for 25,50 and $100 \mathrm{mg} \mathrm{kg}^{-1}$ treatments (Table 4). Shoot Sconcentration in Konya soil for the same $\mathrm{S}$-source and $\mathrm{S}$ doses were respectively found to be $0.31,0.29,0.33$ and $0.30 \%$ (Table 4). S-treatments increased S-concentration of cultivars almost 3 times compared to control treatment with zero S-application $(0.09 \%)$. Shoot S-concentration in Harran soil for zero $\mathrm{K}_{2} \mathrm{SO}_{4}$ treatment was $0.09 \%$, the values were $0.22,0.26$ and $0.27 \%$ respectively for 25,50 and $100 \mathrm{mg} \mathrm{kg}^{-1} \mathrm{~S}$-treatments (Table 4). Therefore, effects of S-sources on shoot S-concentrations were found to be significant (Table 4). While effects of soils, S-sources and cultivars on shoot $\mathrm{N}$-concentrations were found to be significant, effects of S-doses were found to be insignificant (Table 5).

The ratio N/S is accepted as an indicator for nutrition of plants with $\mathrm{S}$. N/S ratios in zero $\mathrm{S}$-doses of $\mathrm{K}_{2} \mathrm{SO}_{4}$ treatment were found to be 13, 12 and 37 for Eskisehir, Konya and Harran soils, respectively. Similar results were also observed in $\mathrm{CaSO}_{4}$ and elemental-S treatments (Table 6). Shoot N/S ratio is expected to be < 17:1. Considering such a reference value, $\mathrm{S}$-nutrition level in Eskisehir and Konya soils were thought to be sufficient, whereas the level was not sufficient for plants in Harran soil. Yield increase with additional S-application only in Harran soil, is an indication that N/S ratio could conveniently be used to express S-nutrition levels of plants.

\section{Discussion}

Effects of S-sources with 0, 25, 50 and $100 \mathrm{mg} \mathrm{kg}^{-1}$ doses on average dry matter yields of wheat cultivar grown in three different soils (Eskisehir, Konya and Harran) mostly depended on soils used increase in shoot dry matter yield with S-treatments compared to zero Streatment was observed only in Harran soil (Table 3). Increase in dry matter and kernel yield of plants with sulphur applications was also reported in several literatures. In a field experiment, Mascagni et al. (2008) reported yield increase of wheat with S-treatments only in soils with sandy-loam texture. Researchers also indicated available S-concentration of the soil as below the critical level $\left(8 \mathrm{mg} \mathrm{kg}^{-1}\right)$ and organic material as lower than $1 \mathrm{~g}$ $\mathrm{kg}^{-1}$. Such findings reveal the significance of available $\mathrm{S}$ concentration and organic material content of soils in $\mathrm{S}$ treatments. Available S-concentrations for soils of current greenhouse study were determined as $14.7 \mathrm{mg} \mathrm{SO}_{4}-\mathrm{S} \mathrm{kg}^{-1}$ for Harran soil, $12.2 \mathrm{mg} \mathrm{SO}_{4}-\mathrm{S} \mathrm{kg}^{-1}$ for Eskisehir soil and $18.3 \mathrm{mg} \mathrm{SO} \mathrm{SO}_{4}-\mathrm{Sg}^{-1}$ for Konya soil. Occurrence of positive growth response of plants in S-treatments of Eskisehir soil with the lowest available $\mathrm{S}$ concentration is remarkable. Therefore, not only available $\mathrm{S}$ concentration but also other soil characteristics such as absorptiondesorption capacities are effective in S-nutrition of plants.

Table 4 Effects of different S-doses and different $\mathrm{S}$ sources on shoot $\mathrm{S}$-concentrations $(\%)$ of plants grown in different soils.

\begin{tabular}{|c|c|c|c|c|}
\hline \multirow{2}{*}{ S Form } & \multirow{2}{*}{$\begin{array}{c}\text { S Doses } \\
\left(\mathrm{mg} \mathrm{kg}^{-1}\right)\end{array}$} & Eskişehir & Konya & Harran \\
\hline & & \multicolumn{3}{|c|}{ Shoot S Concentrations (\%) } \\
\hline \multirow{4}{*}{$\mathrm{K}_{2} \mathrm{SO}_{4}$} & 0 & 0.22 & 0.31 & 0.09 \\
\hline & 25 & 0.21 & 0.29 & 0.22 \\
\hline & 50 & 0.22 & 0.33 & 0.26 \\
\hline & 100 & 0.22 & 0.3 & 0.27 \\
\hline \multirow{4}{*}{$\mathrm{CaSO}_{4}$} & 0 & 0.21 & 0.26 & 0.08 \\
\hline & 25 & 0.22 & 0.3 & 0.21 \\
\hline & 50 & 0.24 & 0.3 & 0.24 \\
\hline & 100 & 0.25 & 0.28 & 0.26 \\
\hline \multirow{4}{*}{$\mathrm{S}$} & 0 & 0.19 & 0.36 & 0.08 \\
\hline & 25 & 0.2 & 0.34 & 0.11 \\
\hline & 50 & 0.21 & 0.3 & 0.16 \\
\hline & 100 & 0.22 & 0.3 & 0.23 \\
\hline
\end{tabular}

LSD $_{0,05}$ (Soil, S-Form, S-Dose): 0.0121; 0.0094; 0.0098

Table 5 Effects of different S-doses and different Ssources on shoot $\mathrm{N}$-concentrations $(\%)$ of plants grown in different soils.

\begin{tabular}{|c|c|c|c|c|}
\hline \multirow{2}{*}{ S Form } & \multirow{2}{*}{$\begin{array}{l}\text { S Doses } \\
\left(\mathrm{mg} \mathrm{kg}^{-1}\right)\end{array}$} & Eskişehir & Konya & Harran \\
\hline & & \multicolumn{3}{|c|}{ Shoot N Concentrations (\%) } \\
\hline \multirow{4}{*}{$\mathrm{K}_{2} \mathrm{SO}_{4}$} & 0 & 2.87 & 3.85 & 3.13 \\
\hline & 25 & 2.95 & 3.62 & 2.77 \\
\hline & 50 & 3.37 & 3.59 & 2.79 \\
\hline & 100 & 2.93 & 3.62 & 2.74 \\
\hline \multirow{4}{*}{$\mathrm{CaSO}_{4}$} & 0 & 3.4 & 3.58 & 2.61 \\
\hline & 25 & 3.29 & 4.05 & 2.74 \\
\hline & 50 & 2.98 & 3.72 & 2.73 \\
\hline & 100 & 3.19 & 3.42 & 2.79 \\
\hline \multirow{4}{*}{$S$} & 0 & 2.98 & 4.13 & 2.56 \\
\hline & 25 & 2.79 & 3.97 & 3.04 \\
\hline & 50 & 3.08 & 3.54 & 3.08 \\
\hline & 100 & 3.21 & 3.8 & 2.8 \\
\hline
\end{tabular}

LSD $_{0,05}$ (Soil, S-Form, S-Dose): $0.128 ; 0.081 ; \mathrm{ns}$

Table 6 Effects of different S-doses and different Ssources on shoot N/S ratios of plants grown in different soils.

\begin{tabular}{l|cccc}
\hline \multirow{2}{*}{$S$ Form } & $\begin{array}{c}\text { S Doses } \\
\left(\mathrm{mg} \mathrm{kg}^{-1}\right)\end{array}$ & Eskişehir & Konya & Harran \\
\cline { 3 - 5 } & 0 & 13 & 12 & 37 \\
$\mathrm{~K}_{2} \mathrm{SO}_{4}$ & 25 & 14 & 13 & 12 \\
& 50 & 15 & 11 & 11 \\
& 100 & 13 & 12 & 10 \\
\hline \multirow{4}{*}{$\mathrm{CaSO}_{4}$} & 0 & 16 & 14 & 35 \\
& 25 & 15 & 14 & 13 \\
& 50 & 13 & 12 & 11 \\
& 100 & 13 & 12 & 11 \\
\hline \multirow{5}{*}{} & 0 & 15 & 11 & 32 \\
& 25 & 14 & 12 & 27 \\
& 50 & 14 & 12 & 20 \\
& 100 & 15 & 13 & 12 \\
\hline
\end{tabular}


Significance of soil properties on S-nutrition of plants was also indicated by Sherer (2009). Compared to control treatment, an increase of 47 to $60 \%$ in shoot dry matter yield was observed in Harran soil with $\mathrm{CaSO}_{4}$ treatments. Zörb et al. (2009) carried out a greenhouse experiment and observed three times higher kernel yield with $\mathrm{S}$ treatments $\left(0.1\right.$ and $0.2 \mathrm{~g} \mathrm{pot}^{-1}$, respectively as medium and high level) than in control treatment. In the same study, significant yield increase was observed in Batis cultivar with high S-treatment level. However yield increase of Türkis cultivar with S-treatments at late period was relatively insignificant. The effects of S-treatments on wheat growth and yield were also reported by field experiments (Habtegebrial and Singh, 2009). Researchers investigated the effects of different $\mathrm{N}(0,100$ and $180 \mathrm{~kg}$ $\left.\mathrm{ha}^{-1}\right)$ and $\mathrm{S}\left(0,20,40\right.$ and $\left.60 \mathrm{~kg} \mathrm{ha}^{-1}\right)$ treatments on yields of wheat cultivars grown in two different soils. They observed increasing yields with increasing doses of individual elements, and obtained even higher yield increase with optimized $\mathrm{N}$ and S-treatments. While average kernel yield of Shehan wheat cultivar in control treatment with zero $\mathrm{N}$ and $\mathrm{S}$-applications was 2.60 ton ha ${ }^{1}$, the yields in 20,40 and $60 \mathrm{~kg} \mathrm{ha}^{-1} \mathrm{~S}$-treatments were found to be $2.80,3.53$ and 3.19 ton $\mathrm{ha}^{-1}$ respectively. Yields for $100 \mathrm{~kg} \mathrm{ha}^{-1}$ and increasing S-doses were found to be $2.73,3.86,3.73$ and $3.56 \mathrm{t} \mathrm{ha}^{-1}$ respectively. Insignificant effects of S-treatments on $\mathrm{N}$-intake or concentration of plants were presented in Table 4. Erdem (2004) also applied different S-doses to soils from different regions and observed that increasing $\mathrm{N}$ concentrations in plant shoots increased the $\mathrm{S}$ and $\mathrm{N}$ concentrations. Shoot N/S ratio is a clear indicator for $\mathrm{S}$ nutrition of plants and a ratio below 17:1 is reported as the ideal level for S-nutrition of plants (Scherer, 2001, Sarda et al., 2014). In present study, N/S ratio of Harran soil was above 17 which was 37 in control treatment with zero S-application. The ratios of $\mathrm{N} / \mathrm{S}$ for all the other treatments were less than 17 (Table 6). Such findings indicated that N/S ratio under controlled conditions could be a reliable indicator for S-nutrition of plants. Zörb et al. (2009) reported that N/S ratio was decreased from 32 to 22 with S-treatments in wheat cultivars. N/S ratio is also a reliable parameter in indicating $S$-nutrition of wheat at the end of tillering and during flag leaf formation period. Investigation of such parameters is highly important to prevent yield and quality losses in plants due to $\mathrm{S}$ defficiency (Zhao et al., 1999; Blake-Kalff et al., 2002; Staugaitis et al., 2014). Although there are several researches carried out to determine the most reliable parameter for S-deficiency of wheat, a consensus on a single parameter has not been reached yet (Scherer, 2001). Among the previously investigated parameters, total S (Pinkerton, 1998), sulfate (Scaife and Burns, 1986), sulfate percentage in total S (Spencer and Freney, 1980) and glutathione (Zhao et al., 1996) were accepted as the most reliable parameters for S-nutrition of wheat. However, these parameters may vary based on plant growth period, parts of plants over which analysis are performed, place and conditions of experiments and analytical methods used in laboratories. S-sources had similar effects on chlorosis level (spad value) (Table 2), shoot dry matter yield (Table 3 ), $\mathrm{S}$ and $\mathrm{N}$-concentrations (Table 4 and 5). Although studies reporting indifferent effects of S-sources on wheat yield (Ryant and Skladanka, 2009), there are several researches indicating the significance of S-source. Girma et al. (2005) carried out a 7-year field study to investigate the effects of elemental $S$ and $\mathrm{CaSO}_{4}$ treatments on kernel yield of winter gremineous forage crop. The yield increase with $\mathrm{CaSO}_{4}$ treatments was higher than that of elemental-S treatments. They also indicated significant but varying effects of Streatments on kernel yield. Results of current study presented the significant effects of S-treatments on plant growth and yield mostly based on soil properties those affecting the availablity of S-levels.

In Conclusion's; effects of different S-treatments and S-forms on symptom level, growth, shoot dry matter yield, shoot $\mathrm{S}, \mathrm{N}$ concentration and N/S ratio varied based on soil types. The results indicated significant effects of S-treatments on plant growth and yield mostly based on soil properties, especially the available S-levels.

\section{References}

Anonymous. 2001. Turkish environmental health and air quality and research lab. Reports of Hifzisihha Health Research Institute; Turkish Ministry of Health: Ankara, Turkey.

Blake-Kalff MMA, Zhao FJ, McGrath SP. 2002. Sulfur deficiency diagnosis using plant tissue analysis. Proceedings of Fertilizer Society 503:1-23.

Bloem E, Haneklaus S, Schnug E. 2002. Optimization of a method for soil sulphur extraction. Comm. In Soil Sci. And Plant Anal. 33(1-2): 41-51.

Capaldi FR, Gratao PL, Reis AR, Lima LW, Azevedo RA. 2015. Sulfur Metabolism and Stress Defense Responses in Plants. Tropical Plant Bio.DOI 10.1007/s12042-015-9152-1.

Pinkerton A. 1998. Critical sulfur concentrations in oilseed rape (Brassica napus) in relation to nitrogen supply and to plant age. Australian Journal of Agricultural Research 32: 203-212.

Erdem H. 2004. The effect of sulphur application on dry matter production of wheat in different soils under greenhouse condition. University of Cukurova, Institute of Natural and Applied Sciences, Adana.

Eriksen J, Thorup-Christensen K, Askegard M. 2004. Plant availability of catch crop sulfur following spring incorporation. J. Plant Nutr. Soil Sci. 167, 609-615.

Girma K, Mosali J, Freeman KW, Raun WR, Martin KL, Thomason, WE. 2005. Forage and grain yield response to applied sulfur in winter wheat as influenced by source and rate. J. Plant Nutr. 28, 1541-1553.

Habtegebriall K, Singh BR. 2009. Response of Wheat Cultivars to Nitrogen and Sulfur for Crop Yield, Nitrogen Use Efficiency, and Protein Quality in the Semiarid Region. Journal of Plant Nutrition, 32: 1768-1787.

$\mathrm{Hu}$ ZY, Zhao FJ, McGrath SP. 2005. Sulphur fractionation in calcareous soils and bioavailability to plants. Plant Soil 268, 103-109.

Inal A, Gunes A, Alpaslan M, Adak MS, Taban S, Eraslan F. 2003. Diagnosis of Sulfur deficiency and effects of sulfur on yield and yield components of wheat grown in Central Anatolia, Turkey. Journal of Plant Nutrition 26: 1483-1498.

Jonard M, Fürst A, Verstraeten A, Thimonier A, Timmermann V, Potočić N, Rautio, P. 2015. Tree mineral nutrition is deteriorating in Europe. Global change biology,21(1), 418-430.

Kalaycı M. 2005. Örneklerle Jump Kullanımı ve Tarımsal Araştırma İçin Varyans Analiz Modelleri. Eskişehir. Anadolu Tarımsal Araştırma Enstitüsü Müdürlüğü. Yayın No: 21 
Mascagni HJJr, Harrison SA, Padgett, GB. 2008. Influence of sulfur fertility on wheat yield performance on alluvial and upland soils. Commun. Soil Sci. Plant Anal. 39, 2133-2145.

McGrath SP, Zhao, FJ, Blake-Kalff, MM. 2002. History and outlook for sulphur fertilisers in Europe. Proc. No. 497, International Fertiliser Society, York, U.K.

Ryant P, Skladanka J. 2009. The effect of applications of various forms of sulfur on the yields and quality of grass forage. Acta Agriculturae Scandinavica Section B - Soil and Plant Science, 59: 208-216

Sarda X, Diquelou S, Abdallah M, Nesi N, Cantat O, Le Gouee P, Ourry A. 2014. Assessment of sulphur deficiency in commercial oilseed rape crops from plant analysis. The Journal of Agricultural Science, 152(04), 616-633.

Scaife A, Burns I.G. 1986. The sulfate-S/total S ratio in plants as an index of their sulfur status. Plant and Soil 91: 61-71.

Schaper H, Chocko EK. 1991. Sulphur availability Rubuco content, and photosynthetic rate of soybean. Crop Sci. 37: 1801-1806.

Scherer NW. 2001. Sulfur in crop production. European Journal of Agronomy 14:81-111.

Scherer HW. 2009. Sulfur in soils. J. Plant Nutr. Soil Sci. 172, 32633. Review Article.

Schonhof I, Blankenburg D, Müller S, Krumbein A. 2007. Sulfur and nitrogen supply influence growth, product appearance, and glucosinolate concentration of broccoli. J. Plant Nutr. Soil Sci. $170,65-72$.
Spencer K, Freney JR. 1980. Assessing the sulfur status of field grown wheat by plant analysis. Agronomy Journal 72(3): 469476.

Staugaitis G, Braziene Z, Marcinkevicius A, Mazeika R, Antanaitis S, Staugaitiene R. 2014. Spring barley as affected by nitrogen and sulphur fertiliserrates calculated using different diagnostic methods. Zemdirbyste-Agriculture, vol. 101, No. 4, p. 373-380.

Zehra S, Khan MA. 2014. Total sulphur amino acid requirement and maximum cysteine replacement value for methionine for fingerling Catla catla (Hamilton). Aquaculture Research, 1-14. doi:10.1111/are.12493.

Zhao FJ, Hawkesford MJ, Warrilow AGS, McGrath, SP, Clarkson DT. 1996. Responses of two wheat varieties to sulfur addition and diagnosis of S deficiency. Plant and Soil 181(2): 317-327.

Zhao FJ, Hawkesford MJ, McGrath SP. 1999. Sulphur assimilation and effects on yield and quality of wheat. J. Cereal Sci. 30, 117.

Zörb C, Steinfurth D, Seling S, Langenkamper G, Koehler P, Wieser H, Lindhauer, MG, Karl HM. 2009. Quantitative Protein Composition and Baking Quality of Winter Wheat as Affected by Late Sulfur Fertilization. J. Agric. Food Chem. 57, 38773885 . 